\title{
Effects of different model diets on milk composition and expression of genes related to fatty acid synthesis in the mammary gland of lactating dairy goats
}

\author{
H. Zhang, C. J. Ao, ${ }^{1}$ Khas-Erdene, L. W. Song, and X. F. Zhang \\ Department of Animal Science, Inner Mongolia Agricultural University, Hohhot, Inner Mongolia 010018, P. R. China
}

\begin{abstract}
This study examined the effects of different roughage diets on milk composition and the expression of key genes associated with fatty acid (FA) synthesis in the mammary gland of lactating dairy goats. Eight multiparous lactating goats (body weight $=43.6 \pm 2.5 \mathrm{~kg}$, $90 \pm 12 \mathrm{~d}$ in milk) fitted with external pudic artery and subcutaneous abdominal vein catheters were assigned to 2 treatments in a crossover design. The goats were fed different roughage diets with a similar concentrateto-roughage ratio. The diets were (1) a high-quality roughage treatment (HQR) containing 28.5\% Chinese wildrye hay, $19 \%$ corn silage, $9.5 \%$ alfalfa, and $43 \%$ concentrate or (2) a low-quality roughage treatment (LQR) containing 28\% Chinese wildrye hay, 28\% corn stover, and $44 \%$ concentrate, on a dry matter basis. Each feeding period lasted $21 \mathrm{~d}$. The first $18 \mathrm{~d}$ served as an adaptation period, and the last $3 \mathrm{~d}$ served as a sample collection period. Dry matter intake, milk yield, and milk composition were measured. Milk and blood samples were collected for FA analysis. Mammary gland biopsies were performed after milking on the last day of each period and the tissues were analyzed for the mRNA expression of acetyl-coenzyme A carboxylase- $\alpha$ $(A C A C A), \mathrm{FA}$ synthase $(F A S N)$, stearoyl CoA desaturase $(S C D)$, and lipoprotein lipase $(L P L)$. Dry matter intake and milk yield were not affected by the treatments. Milk fat (3.16 vs. 2.96\%) and protein (2.99 vs. $2.89 \%$ ) contents were higher in HQR goats than in LQR goats, and milk fat yield tended to be higher in $\mathrm{HQR}$ goats (16.7 vs. $15.1 \mathrm{~g} / \mathrm{d})$. Milk FA composition was not different between treatments, except for C18:3n-3 (0.27 vs. $0.15 \mathrm{~g} / 100 \mathrm{~g})$. Compared with LQR goats, HQR goats had a higher vein concentration of total FA $(0.62$ vs. $0.44 \mathrm{mg} / \mathrm{mL}$ ). In HQR goats, the mammary balance of total FA increased (9.17 vs. $5.51 \mathrm{~g} / \mathrm{d}$ ), whereas the clearance rate of total FA decreased (103.03 vs. 138.25 $\mathrm{L} / \mathrm{d}$ ). No differences were found in mammary blood flow, artery concentration, and mammary uptake of FA
\end{abstract}

Received June 4, 2013.

Accepted February 9, 2015.

${ }^{1}$ Corresponding author: changjinao@aliyun.com. between treatments. Compared with LQR, the expression of FASN and $A C A C A$ tended to be increased by 20 and $18 \%$, and the expression of $L P L$ and $S C D$ were increased by 39 and $50 \%$ in HQR, respectively. The results demonstrated that diets with HQR can increase milk fat content and yield as well as the expression of $L P L$ and $S C D$ in the mammary gland of dairy goats.

Key words: dairy goat, mammary gland, fatty acid composition

\section{INTRODUCTION}

Manipulation of ruminant milk yield and composition through dietary means is relatively straightforward. Although the tremendous advances achieved over the past century in increasing milk yield are due primarily to genetic improvements, feeding practices and nutritional knowledge have also contributed significantly. Effects of diet on milk yield (Gagliostro and Chilliard, 1991; Nudda et al., 2009) and on milk composition, specifically on the FA profile (Weiss and Wyatt, 2006; Odongo et al., 2007; Luna et al., 2008), have been investigated extensively. In addition, the relationships between diet and milk yield, as well as milk composition in cows, goats, and sheep, and factors that affect these relationships have been investigated (Min et al., 2005; Moate et al., 2008; Desnoyers et al., 2011). Compared with protein or lactose, milk fat has a greater sensitivity to dietary manipulation. Thus, nutritional manipulation is an effective way to alter the yield and FA composition of milk. Fatty acids are classified into 2 main categories: short- to medium-chain FA (C4 to $\mathrm{C} 14$ ), which are synthesized de novo in the mammary gland, and longchain FA (>C16), which arise from triacylglycerides or NEFA in arterial blood. Palmitic acid (C16) is present in both the mammary gland and arterial blood.

There have been numerous in vitro studies on the metabolic pathways of nutrient utilization by mammary glands, including intake, transfer, and synthesis (Bauman, et al., 2006; Harvatine et al., 2009). However, in vivo studies that examine the effect of various nutritional regimens on the activity of mammary gland function are limited. Changes in diet could affect the expression of key mammary lipogenic enzymes, 
including short-chain FA de novo synthesis genes acetyl-coenzyme A carboxylase- $\alpha(A C A C A)$ and fatty acid synthase $(F A S N)$, blood uptake FA metabolism gene lipoprotein lipase $(L P L)$, and MUFA synthesis rate-limiting enzyme stearoyl $\mathrm{CoA}$ desaturase $(S C D)$ in the bovine. However, some literature demonstrated the expression of these genes in goats (Bernard et al., 2005, 2008, 2009).

Some studies (Kelly et al., 1998; Chilliard et al., 2000; Dewhurst et al., 2001) have illustrated that the forage effect on FA composition of milk in ruminants is particularly evident. However, high-quality alfalfa hay is in short supply in China, whereas corn stover is plentiful (Zhu et al., 2013). Thus, the current study aims to investigate the effects of 2 different roughage diets on the FA composition and milk fat synthesis in relation to the expression of lipogenic genes that are involved in de novo synthesis, uptake, and desaturation of FA in lactating goats.

\section{MATERIALS AND METHODS}

\section{Animals and Diets}

The current study was approved by the Animal Care and Ethics Committee of the Inner Mongolia Agricultural University. The goats were obtained from a local dairy goat breeder Guanzhong Dairy Goats (Shanxi, China). Eight multiparous lactating goats $(\mathrm{BW}=43.6$ $\pm 2.5 \mathrm{~kg}$, DIM $=90 \pm 12$ ) fitted with external pudic artery (EPA) and subcutaneous abdominal vein catheters were assigned to 2 treatments in a crossover design. For a 21-d trial, the first $18 \mathrm{~d}$ served as an adaptation period and the last $3 \mathrm{~d}$ served as a sample collection period. The experimental goats were housed in individual stalls with free access to water, and their rooms were environmentally controlled with artificial ventilation. The goats were milked twice daily at 0800 and $1600 \mathrm{~h}$ and were fed forage ad libitum and grain concentrate separately after each milking. Forages were premixed according to the ratio of the experimental diets. The amount of the concentrates was calculated and fed to the goats based on the amount of the consumed forages each day to maintain relatively constant forage-to-concentrate ratio. The actual consumed experimental diets are described in Table 1. The diets were (1) a high-quality roughage treatment (HQR) containing $28.5 \%$ Chinese wildrye hay, $19 \%$ corn silage, $9.5 \%$ alfalfa, and $43 \%$ concentrate (CP: $14.5 \%$, NDF: $\left.38.3 \%, \mathrm{NE}_{\mathrm{L}}: 1.54 \mathrm{Mcal} / \mathrm{kg}, \mathrm{Ca}: 0.63 \%, \mathrm{P}: 0.37 \%\right)$ and (2) a low-quality roughage treatment (LQR) containing 28\% Chinese wildrye hay, $28 \%$ corn stover, and $44 \%$ concentrate (CP: $11.1 \%, \mathrm{NDF}: 47.8 \%, \mathrm{NE}_{\mathrm{L}}: 1.36 \mathrm{Mcal} /$ $\mathrm{kg}$, Ca: $0.50 \%$, P: $0.36 \%$ ) on a DM basis. Diets were
Table 1. Ingredient and chemical composition of diets consumed by lactating dairy goats

\begin{tabular}{lcc}
\hline & \multicolumn{2}{c}{ Treatment $^{1}$} \\
\cline { 2 - 3 } Item & HQR & LQR \\
\hline Ingredient, \% of DM & & \\
Chinese wildrye hay & 28.5 & 28.0 \\
Alfalfa hay & 9.5 & - \\
Corn silage & 19.0 & - \\
Corn stover & - & 28.0 \\
Corn & 28.2 & 28.8 \\
Soybean meal & 5.7 & 5.8 \\
Cottonseed cake & 3.8 & 3.9 \\
Wheat bran & 3.9 & 3.9 \\
Premix & 1.0 & 1.1 \\
Salt & 0.1 & 0.1 \\
Limestone & 0.4 & 0.4 \\
Total & 100.0 & 100.0 \\
Chemical composition & & \\
CP, \% of DM & 14.5 & 11.1 \\
MP, \% of DM & 9.71 & 6.42 \\
Ether extract, \% of DM & 2.93 & 2.36 \\
NDF, \% of DM & 38.3 & 47.8 \\
ADF, \% of DM & 23.2 & 31.1 \\
Ca, \% of DM & 0.61 & 0.50 \\
P, \% of DM & 0.37 & 0.36 \\
NE ${ }^{3}$ Mcal/kg & 1.54 & 1.36 \\
\hline
\end{tabular}

${ }^{1}$ Treatment: HQR = high-quality roughage; forage is composed of hay, corn silage, and alfalfa; LQR = low-quality roughage; forage is composed of hay and corn straw.

${ }^{2}$ Premix formula: $20 \% \mathrm{Ca}\left(\mathrm{HCO}_{3}\right)_{2}, 40 \%$ Mineral salts.

${ }^{3}$ Calculated based on the data provided by NRC (2007).

formulated based on NRC (2007) recommendations to provide sufficient $\mathrm{NE}_{\mathrm{L}}$, protein, vitamins, and minerals.

\section{Sample Collection}

Samples of feed offered and orts were collected every day during the experimental period to determine the daily DMI. Samples of dietary ingredients were collected at the beginning of the experimental period and stored at $-20^{\circ} \mathrm{C}$ until analyzed for the nutrient components of diets. The individual milk yield was recorded daily at morning and evening milkings throughout the experiment. Milk samples were collected on the last week of each experimental period, on d 19 to 21, and the samples were mixed thoroughly and divided into 2 portions. One aliquot was stored at $4^{\circ} \mathrm{C}$ with a preservative until analyzed for milk composition and SCC by infrared analysis (MilkoScan minor, Foss, Hillerod, Denmark). The other aliquot was stored at $-20^{\circ} \mathrm{C}$ until analyzed for FA composition by GC. Mammary blood flow (MBF) was measured by an indicator dilution technique that uses $p$-aminohippuric acid (PAH; Ten Have et al., 1995). The PAH solution $(15 \mathrm{mg} / \mathrm{mL})$ was infused continuously $(750 \mathrm{mg}$ of $\mathrm{PAH} / \mathrm{h}$ ) for $6 \mathrm{~h}$ into the EPA catheters oriented to the mammary gland using a constant flow pump (longer pump, BT100-1L, 
China) on d 19. For MBF analysis, blood samples were collected 5 times at 1 -h intervals beginning $1 \mathrm{~h}$ after the start of the PAH infusion on d 19. For plasma FA analysis, blood samples of both EPA and subcutaneous abdominal vein were collected 6 times daily at 4 -h intervals on d 20 and 21 .

\section{FA Analysis}

Milk FA were extracted according to the procedures outlined by Chouinard et al. (1999) with minor modifications. The milk samples from individual goats were extracted in $4 \mathrm{~mL}$ of hexane and isopropanol $(3 / 2$ proportion vol/vol) solution followed by $2 \mathrm{~mL}$ of sodium sulfate solution and then centrifuged at 2,500 $\times$ $g$ for $20 \mathrm{~min}$ at $20^{\circ} \mathrm{C}$. The supernatant was decanted into a hydrolysis tube and then dried under nitrogen flow. Then, $2 \mathrm{~mL}$ of $\mathrm{NaOCH}_{3}$-methanol were added to the dry sample. The mixture was thoroughly mixed using a vortex mixer and was heated at $50^{\circ} \mathrm{C}$ for 15 min. After the cooling period, $2 \mathrm{~mL}$ of hydrochloric acid or methanol was added to the mixture allowing the mixture to react for $1.5 \mathrm{~h}$ at $80^{\circ} \mathrm{C}$. After cooling to room temperature, $6 \mathrm{~mL}$ of hexane and $3 \mathrm{~mL}$ of deionized water were added to the mixture. The mixture was thoroughly homogenized using a vortex mixer and then centrifuged $\left(2,500 \times g\right.$ for $20 \mathrm{~min}$ at $\left.20^{\circ} \mathrm{C}\right)$. The supernatant was decanted into a graduated tube with hexane and adjusted to a volume of $10 \mathrm{~mL}$. Anhydrous sodium sulfate (approximately $1 \mathrm{~g}$ ) was then added. Plasma FA were extracted using a similar method described previously for milk FA analysis with minor modifications. The plasma samples $(1 \mathrm{~mL})$ of each goat were decanted into $10-\mathrm{mL}$ centrifuge tubes and $5 \mathrm{~mL}$ of hexane and isopropanol (3/2 proportion vol/vol) solution were added. The mixtures were thoroughly mixed using a vortex mixer for $2 \mathrm{~min}$. The supernatants were decanted into hydrolysis tubes and dried under a stream of gaseous nitrogen. Hexane $(0.5 \mathrm{~mL})$ and methanol $(1 \mathrm{~mL})$ were added into the dried sample. The subsequent steps were identical to the procedures used for milk FA analysis.

Fatty acid methyl esters were measured using GC. The machine used was a Shimadzu GC-2014 system (Shimadzu, Kyoto, Japan) fitted with a HP-88 fusedsilica capillary column $[100 \mathrm{~m} \times 0.25 \mathrm{~mm}$ (i.d.) with $0.2 \mu \mathrm{m}$ film thickness; Agilent, Santa Clara, CA]. The column temperature was initially maintained at $120^{\circ} \mathrm{C}$ for $10 \mathrm{~min}$ and then heated to $230^{\circ} \mathrm{C}$ at $3.2^{\circ} \mathrm{C} / \mathrm{min}$ and maintained for $35 \mathrm{~min}$. The temperature of the injector was maintained at $250^{\circ} \mathrm{C}$ and the temperature of detector was maintained at $300^{\circ} \mathrm{C}$. The injection volume was $1 \mu \mathrm{L}$. Each peak was identified using pure methyl ester standards (Supelco, Bellefonte, PA).

\section{Mammary Tissue Sampling and RNA Isolation}

Mammary tissue biopsies were performed $2 \mathrm{~h}$ after the morning milking on the last day of each treatment period. The biopsy procedure was according to the method of Farr et al. (1996) with modifications. The goats were administered xylazine hydrochloride (1 $\mathrm{mL}$, i.v.) approximately $15 \mathrm{~min}$ before the biopsy, and a procaine hydrochloride subdermal block was administered in a circular pattern surrounding the incision site. An incision $(1.5-2 \mathrm{~cm})$ was made in the skin on the midpoint section of a rear quarter of the mammary gland and the connective tissue was dissected to reveal the gland capsule. The mammary tissue biopsies (approximately $20 \mathrm{mg} /$ animal) were rinsed in $0.9 \%$ sterile saline solution and then frozen in liquid nitrogen. The samples were kept at $-80^{\circ} \mathrm{C}$ until RNA extraction. Total RNA were isolated from each $20 \mathrm{mg}$ of the frozen mammary biopsy using an RNA Prep Pure Tissue kit (Tiangen Biotech Co. Ltd., Beijing, China). The RNA purity was determined by measuring the $260 / 280$ ratios using a BioTek Synergy H4 Hybrid Reader (BioTek, Winooski, VT), and the mRNA integrity was assessed by agarose gel electrophoresis. Crisp $28 \mathrm{~S}$ and $18 \mathrm{~S}$ rRNA bands indicated intact RNA.

\section{Reverse Transcription and Quantitative Reverse Transcription-PCR}

The cDNA was synthesized using $100 \mathrm{ng}$ of RNA in $2 \mu \mathrm{L}$ that was mixed with $2 \mu \mathrm{L}$ of $5 \times$ PrimeScript RT Master Mix and $6 \mu \mathrm{L}$ of DNase/RNase-free water (TaKaRa, Tokyo, Japan). The reaction was performed in the following temperature program: $37^{\circ} \mathrm{C}$ for $15 \mathrm{~min}$, and $85^{\circ} \mathrm{C}$ for $5 \mathrm{~s}$. Quantitative reverse transcription (RT)-PCR was performed using the PrimeScript RT reagent Kit (TaKaRa) in a $20-\mu \mathrm{L}$ reaction volume with $10 \mu \mathrm{L}$ of $2 \times$ SYBR premix Ex TaqII (TaKaRa), 0.4 $\mu \mathrm{L}$ of each of $10 \mu \mathrm{M}$ of forward and reverse primers, and $7.2 \mu \mathrm{L}$ of DNase/RNase-free water in 96-well microwell plates of a Bio-Rad IQ5 Multiclor Real-time PCR Detection System (Hercules, CA). Moreover, the quantitative RT-PCR was conducted under the following conditions: a predenaturation for $30 \mathrm{~s}$ at $95^{\circ} \mathrm{C}, 40$ cycles of denaturation for $15 \mathrm{~s}$ at $95^{\circ} \mathrm{C}$, annealing for 20 $\mathrm{s}$ at $58^{\circ} \mathrm{C}$, and extension for $30 \mathrm{~s}$ at $72^{\circ} \mathrm{C}$. The RT-PCR analysis was performed through the $2^{-\Delta \Delta \mathrm{CT}}$ method (Livak and Schmittgen, 2001), and GAPDH was used as the reference gene. The primer sequences and annealing temperature are displayed in Table 2. The primers were designed according to Ollier et al. (2009) and were synthesized by Shanghai Sangon Biological Engineering and Technology Service Co. Ltd. (Shanghai, China). 
Table 2. Polymerase chain reaction amplification primer information and annealing temperature

\begin{tabular}{|c|c|c|c|}
\hline Gene $^{1}$ & $\begin{array}{l}\text { Accession } \\
\text { number }\end{array}$ & Sequence $\left(5^{\prime} \text { to } 3^{\prime}\right)^{2}$ & $\begin{array}{c}\text { Annealing } \\
\text { temperature }\left({ }^{\circ} \mathrm{C}\right)\end{array}$ \\
\hline$G A P D H$ & AF035421 & $\begin{array}{l}\text { F: GTCGGAGTGAACGGATTTGG } \\
\text { R: AACGATGTCCACTTTGCCAGTA }\end{array}$ & 59 \\
\hline$L P L$ & AF228667 & $\begin{array}{l}\text { F: TTCAGAGGCTATTACTGGAAATCC } \\
\text { R: ATGTCAATCACAGCATTCATTCTA }\end{array}$ & 58 \\
\hline$A C A C A$ & NM_0010092 & $\begin{array}{l}\text { F: CATGGAAATGTACGCGGACC } \\
\text { R: GGTGGTAGATGGGAAGGAGGA }\end{array}$ & 58 \\
\hline$F A S N$ & DQ223929 & $\begin{array}{l}\text { F: ACAGCCTCTTCCTGTTTGACG } \\
\text { R: CTCTGCACGATCAGCTCGAC }\end{array}$ & 58.5 \\
\hline$S C D$ & AF325499 & $\begin{array}{l}\text { F: TGCTGACAACTTATCTGGATGC } \\
\text { R: AAGGAATCCTGCAAACAGCTA }\end{array}$ & 58 \\
\hline
\end{tabular}

${ }^{1} G A P D H=$ glyceraldehyde-3-phosphate dehydrogenase; $L P L=$ lipoprotein lipase; $A C A C A=$ acetyl-coenzyme A carboxylase $\alpha ; F A S N=$ fatty acid synthase; $S C D=$ stearoyl-coenzyme A desaturase.

${ }^{2} \mathrm{~F}=$ forward primer; $\mathrm{R}=$ reverse primer.

\section{Calculation and Statistical Analysis}

Mammary blood flow was calculated by the method of Katz and Bergman (1969), using the formulas

$$
\mathrm{MBF}=\mathrm{PAH}_{\mathrm{IR}} \div \mathrm{PAH}_{[\mathrm{V}-\mathrm{A}]} \times[100 \div(100-\mathrm{HT})]
$$

where $\mathrm{PAH}_{\mathrm{IR}}$ is the infusion rate of $\mathrm{PAH}, \mathrm{PAH}_{[\mathrm{V}-\mathrm{A}]}$ is veno-arterial concentration differences of PAH, and HT is hematocrit percent;

$$
\text { Mammary uptake }=(\mathrm{AC}-\mathrm{VC}) \times \mathrm{MBF},
$$

where $\mathrm{AC}$ and $\mathrm{VC}$ are concentrations of $\mathrm{FA}$ in the EPA and subcutaneous abdominal vein, respectively;

$$
\text { Clearance rate }=\mathrm{AC} \times \mathrm{MBF} \div \mathrm{VC}-\mathrm{MBF}
$$

(Hanigan et al., 1998); and

Mammary balance $=$ milk output - arterial uptake

(Tagari, et al., 2008, Delgado-Elorduy et al., 2002).

Dry matter intake, growth performance, and FA composition were analyzed with the Proc Mixed procedure of SAS 9.0 (SAS Inst. Inc., Cary, NC). The model contained the random effects of goat and fixed effects of period (1 df) and treatment (1 df). Model residuals were examined and were normally distributed for all variables. Least squares means were calculated and are represented with their standard error of the means. The results were deemed significant when $P<0.05$.

To evaluate mRNA quantities, we obtained data as cycle threshold (CT) values. The RT-PCR data analysis was performed on the ratio $\Delta \Delta \mathrm{Ct}\{[\mathrm{CT}$ (target, sample) - CT (reference, sample) $]-[\mathrm{CT}$ (target, control) $-\mathrm{CT}$ (reference, control)] $\}$, using a paired $t$-test on the difference between treatments and presented as mean percentage. Again, the effects of the results were deemed significant at $P$ $<0.05$

\section{RESULTS AND DISCUSSION}

\section{Milk Production and Composition}

The average BW of the goats was $43.6 \pm 2.5 \mathrm{~kg}$ at the start of the experiment, and there was no change in weight during the trial. Milk fat and protein contents were higher $(P<0.05)$ for goats fed HQR than those fed LQR (Table 3). No differences were found in DMI, milk yield, and milk protein yield. Compared with goats fed LQR, milk fat yield tended to be higher in goats fed HQR. As reported by Zhu et al. (2013), milk protein content was higher, but DMI remained constant in cows fed an alfalfa forage diet when compared with cows fed a corn stover forage diet. Other studies (Broderick, 2003; Colmenero and Broderick, 2006) observed that diets with high CP content had only small or negligible effects on DMI, milk yield, and milk protein yield. Also, the same studies observed that diets with high energy contents elicited an increase in milk yield and milk components in dairy cows. Furthermore, in the current study, diet had no effect on lactose yield and content. This result is supported by the findings of Jenkins and McGuire (2006), who showed that lactose content could not be manipulated by diet, except under extreme and unusual feeding situations. In the present study, the TS content was higher $(P<0.05)$ in the goats fed HQR. But the number of somatic cells was not affected by diet and remained within the normal range, thereby indicating the good health status of the dairy goats.

\section{Milk FA Composition}

Roughage quality had no effect on the concentrations of short-, medium-, and long-chain FA, except for 
Table 3. Effects of diets on DMI, milk yield, milk composition, and $\mathrm{SCC}$ in goats

\begin{tabular}{lcccc}
\hline & \multicolumn{2}{c}{ Treatment $^{1}$} & & \\
\cline { 2 - 3 } Item & HQR & LQR & SEM & $P$-value \\
\hline DMI, g/d & $581^{\mathrm{a}}$ & $537^{\mathrm{a}}$ & 45 & 0.18 \\
Milk yield, g/d & $497^{\mathrm{a}}$ & $516^{\mathrm{a}}$ & 102 & 0.13 \\
Fat, \% & $3.16^{\mathrm{a}}$ & $2.96^{\mathrm{b}}$ & 0.05 & 0.01 \\
Fat, g/d & $16.7^{\mathrm{a}}$ & $15.1^{\mathrm{a}}$ & 0.63 & 0.09 \\
Protein, \% & $2.99^{\mathrm{a}}$ & $2.89^{\mathrm{b}}$ & 0.02 & 0.01 \\
Protein, g/d & $15.5^{\mathrm{a}}$ & $14.9^{\mathrm{a}}$ & 0.31 & 0.17 \\
Lactose, \% & $4.24^{\mathrm{a}}$ & $4.20^{\mathrm{a}}$ & 0.03 & 0.32 \\
Lactose, g/d & $22.3^{\mathrm{a}}$ & $21.7^{\mathrm{a}}$ & 0.50 & 0.41 \\
TS, \% & $11.25^{\mathrm{a}}$ & $10.95^{\mathrm{a}}$ & 0.13 & 0.07 \\
TS, g/d & $55.8^{\mathrm{a}}$ & $56.3^{\mathrm{a}}$ & 10.7 & 0.15 \\
SCC, $\times 10^{3} / \mathrm{mL}$ & $202^{\mathrm{a}}$ & $202^{\mathrm{a}}$ & 54 & 0.58 \\
\hline
\end{tabular}

${ }^{\mathrm{a}, \mathrm{b}}$ Means with the same letters within a row are not significantly different $(P<0.05)$.

${ }^{1} \mathrm{HQR}=$ high-quality roughage; forage is composed of hay, corn silage, and alfalfa; LQR = low-quality roughage; forage is composed of hay and corn straw.

C18:3n-3, which was significantly higher $(P<0.01)$, and C18:1 cis-9, which tended to be increased in milk from goats fed HQR (Table 4). Chilliard et al. (2007) observed that the concentration of $\mathrm{C} 18: 3 \mathrm{n}-3$ in milk increased in cows fed high-quality alfalfa hay-based diets. Patel et al. (2013) observed that a low proportion of grass silage with high CP and crude fat level in cow diets increased C18:0 and C18:1 cis-9 of milk compared with cows fed a diet containing a high proportion of grass silage. Our study showed that compared with goats fed LQR, the level of unsaturated fatty acids (UFA) in milk tended to be higher, whereas that of SFA tended to be lower in goats fed HQR. Couvreur et al. (2007) reported diets with higher CP increased the percentage of UFA at the expense of the percentage of SFA of milk fat in dairy cows. Milk fat typically contains a high proportion of SFA and MUFA, as well as a low proportion of PUFA. Generally, UFA is regarded as beneficial to human health in animal models. Thus, it may be stated that consumption of milk from goats fed high-quality roughage diets could elicit potential health benefits to humans.

\section{Mammary Metabolism}

No differences were found in plasma concentrations, except for vein concentration of total FA, which was higher in goats fed HQR when compared with goats fed LQR. The mammary balance of total FA increased, but the clearance rate of total FA decreased in goats fed with $\mathrm{HQR}$ when compared with goats fed LQR. Furthermore, no difference was observed in the mammary uptake of FA (Table 5). The mammary extraction of a nutrient represents the amount of that nutrient removed by the mammary gland as a fraction of the total metabolites present in the blood. Hanigan et al., (1998) suggested that the mammary gland has excess capacity for mammary extraction of the majority of metabolites, as the clearance rate better represents the tissue activity. Compared with goats fed HQR, the clearance rate of total FA was increased and thus the mammary gland expressed more transport activity in goats fed LQR, but because the blood concentrations of total FA were less, there was no change in net uptake. Mammary balance via comparison between mammary glands extracted FA to synthesize milk fat. In our experiment, the mammary balance of total FA increased in goats fed HQR, showing that the milk fat yield increased when the mammary uptake remained steady.

We examined several enzymes that have significant roles in regulating milk fat synthesis. Compared with animals fed LQR, the mammary level of $L P L$, which is involved in FA uptake, increased by $39 \%(P<0.05)$ and the level of $S C D$, which is involved in FA desaturation, increased by $50 \%(P<0.05)$. The levels of $A C A C A$ and FASN, which are involved in de novo FA synthesis tended to be higher, with numerical increases

Table 4. Effects of diets on milk FA composition and content in the goats

\begin{tabular}{|c|c|c|c|c|}
\hline \multirow{2}{*}{$\begin{array}{l}\mathrm{FA}, \mathrm{g} / 100 \mathrm{~g} \\
\text { of } \mathrm{FA}\end{array}$} & \multicolumn{2}{|c|}{ Treatment $^{1}$} & \multirow[b]{2}{*}{ SEM } & \multirow[b]{2}{*}{$P$-value } \\
\hline & HQR & LQR & & \\
\hline C4:0 & 2.32 & 2.24 & 0.15 & 0.34 \\
\hline C6:0 & 2.36 & 2.30 & 0.14 & 0.45 \\
\hline C8:0 & 2.64 & 2.56 & 0.21 & 0.41 \\
\hline C10:0 & 8.86 & 8.95 & 0.73 & 0.88 \\
\hline C11:0 & 0.30 & 0.28 & 0.04 & 0.61 \\
\hline C12:0 & 4.17 & 4.40 & 0.32 & 0.58 \\
\hline C13:0 & 0.23 & 0.23 & 0.03 & 0.96 \\
\hline C14:0 & 11.46 & 12.28 & 0.43 & 0.16 \\
\hline C14:1 & 0.37 & 0.30 & 0.05 & 0.25 \\
\hline C15:0 & 1.12 & 1.11 & 0.06 & 0.96 \\
\hline C15:1 & 0.45 & 0.46 & 0.03 & 0.55 \\
\hline C16:0 & 29.9 & 31.1 & 1.05 & 0.23 \\
\hline C16:1 & 0.54 & 0.58 & 0.03 & 0.38 \\
\hline C17:0 & 0.57 & 0.58 & 0.03 & 0.66 \\
\hline $\mathrm{C} 17: 1$ & 0.31 & 0.30 & 0.02 & 0.43 \\
\hline C18:0 & 7.45 & 7.04 & 0.48 & 0.20 \\
\hline C18:1 trans -9 & 1.22 & 1.13 & 0.10 & 0.21 \\
\hline C18:1 cis-9 & 23.12 & 21.46 & 0.94 & 0.13 \\
\hline C18:2n-6 & 0.98 & 1.48 & 0.36 & 0.24 \\
\hline C20:0 & 0.29 & 0.27 & 0.02 & 0.27 \\
\hline C18:3n-3 & $0.27^{\mathrm{a}}$ & $0.15^{\mathrm{b}}$ & 0.03 & $<0.01$ \\
\hline C20:1 & 0.67 & 0.57 & 0.06 & 0.18 \\
\hline SFA & 71.71 & 73.41 & 0.96 & 0.15 \\
\hline $\mathrm{UFA}^{2}$ & 28.29 & 26.59 & 0.96 & 0.15 \\
\hline PUFA & 1.64 & 2.07 & 0.34 & 0.31 \\
\hline$>16 \mathrm{C}$ & 35.03 & 33.03 & 1.22 & 0.14 \\
\hline$<16 \mathrm{C}$ & 34.27 & 35.16 & 1.47 & 0.58 \\
\hline
\end{tabular}

${ }^{1} \mathrm{HQR}=$ high-quality roughage; forage is composed of hay, corn silage, and alfalfa; LQR = low-quality roughage; forage is composed of hay and corn straw.

${ }^{2} \mathrm{UFA}=$ unsaturated fatty acids. 
Table 5. Effects of diets on mammary blood flow (MBF), plasma concentrations, clearance rate, mammary uptake, and mammary balance of FA in goats

\begin{tabular}{|c|c|c|c|c|}
\hline \multirow[b]{2}{*}{ Item } & \multicolumn{2}{|c|}{ Treatment $^{1}$} & \multirow[b]{2}{*}{ SEM } & \multirow[b]{2}{*}{$P$-value } \\
\hline & HQR & LQR & & \\
\hline $\mathrm{MBF},{ }^{2} \mathrm{~L} / \mathrm{d}$ & 257.9 & 251.3 & 2.8 & 0.54 \\
\hline \multicolumn{5}{|l|}{$\begin{array}{l}\text { Artery concentration, mg/ } \\
\mathrm{mL}\end{array}$} \\
\hline Acetate & 0.07 & 0.083 & 0.01 & 0.68 \\
\hline C16:0 & 0.08 & 0.079 & 0.01 & 0.95 \\
\hline C18:0 & 0.09 & 0.088 & 0.02 & 0.83 \\
\hline $\mathrm{C} 18: 1$ cis-9 & 0.11 & 0.10 & 0.02 & 0.83 \\
\hline C18:2n-6 & 0.11 & 0.108 & 0.02 & 0.84 \\
\hline Total & 0.68 & 0.53 & 0.06 & 0.32 \\
\hline \multicolumn{5}{|l|}{ Vein concentration, $\mathrm{mg} / \mathrm{mL}$} \\
\hline Acetate & 0.04 & 0.05 & 0.01 & 0.81 \\
\hline C16:0 & 0.07 & 0.06 & 0.02 & 0.61 \\
\hline C18:0 & 0.07 & 0.08 & 0.02 & 0.68 \\
\hline C18:1 cis-9 & 0.08 & 0.07 & 0.03 & 0.78 \\
\hline C18:2n-6 & 0.08 & 0.10 & 0.03 & 0.44 \\
\hline Total & 0.62 & 0.44 & 0.05 & 0.02 \\
\hline \multicolumn{5}{|l|}{ Clearance rate,${ }^{3} \mathrm{~L} / \mathrm{d}$} \\
\hline Acetate & 186.32 & 158.84 & 10.55 & 0.13 \\
\hline C16:0 & 52.84 & 83.28 & 10.77 & 0.12 \\
\hline C18:0 & 72.96 & 62.85 & 5.68 & 0.29 \\
\hline $\mathrm{C} 18: 1$ cis-9 & 52.17 & 58.28 & 12.11 & 0.73 \\
\hline C18:2n-6 & 80.83 & 57.42 & 10.18 & 0.15 \\
\hline Total & 103.03 & 138.25 & 5.06 & 0.05 \\
\hline \multicolumn{5}{|l|}{ Mammary uptake, ${ }^{4} \mathrm{~g} / \mathrm{d}$} \\
\hline Acetate & 8.59 & 9.08 & 1.22 & 0.64 \\
\hline C16:0 & 2.68 & 4.53 & 3.09 & 0.22 \\
\hline C18:0 & 4.66 & 2.82 & 2.87 & 0.94 \\
\hline $\mathrm{C} 18: 1$ cis-9 & 7.25 & 3.23 & 5.16 & 0.11 \\
\hline C18:2n-6 & 6.65 & 3.12 & 3.45 & 0.14 \\
\hline Total & 11.43 & 11.83 & 9.28 & 0.84 \\
\hline \multicolumn{5}{|l|}{ Mammary balance, ${ }^{5} \mathrm{~g} / \mathrm{d}$} \\
\hline$\Sigma \leq \mathrm{C} 16^{6}$ & 9.14 & 7.78 & 6.25 & 0.28 \\
\hline C16:0 & 3.14 & 2.89 & 1.30 & 0.52 \\
\hline C18:0 & -3.34 & -3.74 & 1.94 & 0.39 \\
\hline C18:1 cis-9 & 3.21 & 5.57 & 2.84 & 0.21 \\
\hline C18:2n-6 & -0.37 & 1.02 & 2.15 & 0.34 \\
\hline Total & 9.17 & 5.51 & 4.86 & 0.05 \\
\hline
\end{tabular}

${ }^{1} \mathrm{HQR}=$ high-quality roughage; forage is composed of hay, corn silage, and alfalfa; LQR = low-quality roughage; forage is composed of hay and corn straw.

${ }^{2} \mathrm{MBF}=$ mammary blood flow $(\mathrm{L} / \mathrm{d})$ was calculated as $\mathrm{PAH}_{\mathrm{IR}} \div$ $\mathrm{PAH}_{[\mathrm{V}-\mathrm{A}]} \times[100 \div(100-\mathrm{HT})]$, where $\mathrm{PAH}_{\mathrm{IR}}$ is the infusion rate of $\mathrm{PAH}, \mathrm{PAH}_{[\mathrm{V}-\mathrm{A}]}$ is veno-arterial concentration differences of $\mathrm{PAH}$, and HT is hematocrit percent.

${ }^{3}$ Clearance rate was calculated as $\mathrm{AC} \times \mathrm{MBF} \div \mathrm{VC}-\mathrm{MBF}$ (Hanigan et al., 1998), where AC is artery concentration and $\mathrm{VC}$ is vein concentration.

${ }^{4}$ Mammary uptake $(\mathrm{g} / \mathrm{d})$ was calculated as $(\mathrm{AC}-\mathrm{VC}) \times \mathrm{MBF}$, where $\mathrm{AC}$ is artery concentration and $\mathrm{VC}$ is vein concentration.

${ }^{5}$ Mammary balance (g/d) was calculated as milk output - arterial uptake.

${ }^{6} \Sigma \leq \mathrm{C} 16$ (g/d) was calculated as milk concentration of de novo synthesis FA - mammary uptake of acetate.

of 18 and $20 \%$ in goats fed HQR, respectively $(P>$ 0.05 , Figure 1). The relationships between mammary uptake of long-chain FA (LCFA) and the supply of LCFA by EPA, as well as mRNA expression of $L P L$ by the mammary gland in lactating goats, were represented by the multivariate regression model $\mathrm{Y}=98.31$ $\mathrm{X}_{1}-0.24 \mathrm{X}_{2}+35.38\left(\mathrm{R}^{2}=0.80, \mathrm{SE}=17.47, P=0.02\right.$, $\mathrm{P}_{1}=0.01, \mathrm{P}_{2}=0.40$, Figure 2$)$, where $\mathrm{Y}$ represents the mammary uptake of LCFA, $\mathrm{X}_{1}$ represents the mRNA expression of $L P L$, and $\mathrm{X}_{2}$ represents the supply of LCFA by EPA; $\mathrm{P}$ represents the overall $P$-value in the regression, and $\mathrm{P}_{1}$ and $\mathrm{P}_{2}$ represent the $P$-value of the slope of mRNA expression of $L P L$ and slope of supply of LCFA by EPA in the regression, respectively. The relationships between the mRNA levels of $S C D$ in the mammary gland and the supply of C18:1 cis-9 by EPA and the milk fat concentration of C18:1 cis-9 of the 2 treatments in dairy goats was represented by the multivariate regression model $\mathrm{Y}=4.3 \mathrm{X}_{1}+0.09 \mathrm{X}_{2}+2.39$ $\left(\mathrm{R}^{2}=0.78, \mathrm{SE}=1.39, P=0.02, \mathrm{P}_{1}=0.05, \mathrm{P}_{2}=0.29\right.$, Figure 3), where $\mathrm{Y}$ represents the mRNA expression of $S C D, \mathrm{X}_{1}$ represents the milk fat concentration of C18:1 cis-9, $\mathrm{X}_{2}$ represents the supply of $\mathrm{C} 18: 1$ cis-9 by EPA; $\mathrm{P}$ represents the overall $P$-value in the regression, and $\mathrm{P}_{1}$ and $\mathrm{P}_{2}$ represent the $P$-value of the slope of milk fat concentration of $\mathrm{C} 18: 1$ cis-9 and slope of supply of C18:1 cis-9 by EPA in the regression, respectively.

Our results demonstrated that expression of key genes involved in lipid metabolism were highly responsive to changes in milk FA composition. The $A C A C A$ and $F A S N$ activities observed in the mammary glands of goats were in accordance with those observed in goats (Chilliard et al., 1986) in previously published studies. The acetate was the mammary substrate supply in relation to the milk fat output. In the present study, the observed acetate concentration of plasma and the de novo FA synthesis of the key genes $A C A C A$ and $F A S N$ were not significantly different between the 2 treatments. This result explained the underlying reason that the milk fat composition of short- and mediumchain FA was not affected by the treatments.

The level of $L P L$ is critical for the uptake and secretion of LCFA in milk (Iverson et al., 1995). Moreover, Hamosh et al., (1970) reported that the LPL activity is correlated with the level of lipid uptake by the mammary gland in rats. The mammary uptake of LCFA is a function of both LCFA supply by EPA and removal activity, the latter apparently driven by $L P L$ expression. The positive correlation between the mammary uptake of LCFA and the gene expression of $L P L$ in treatments supports that $L P L$ is critical for the uptake of LCFA. The multivariate regression model showed that the mRNA expression of $L P L$ was linear within the observed mammary uptake of LCFA $(P=0.01)$, but the LCFA supply by EPA had no significant effect on mammary uptake of LCFA when the substrate supply was not significantly different $(P=0.40)$. The milk fat content may be affected by $L P L$ through the controlled 


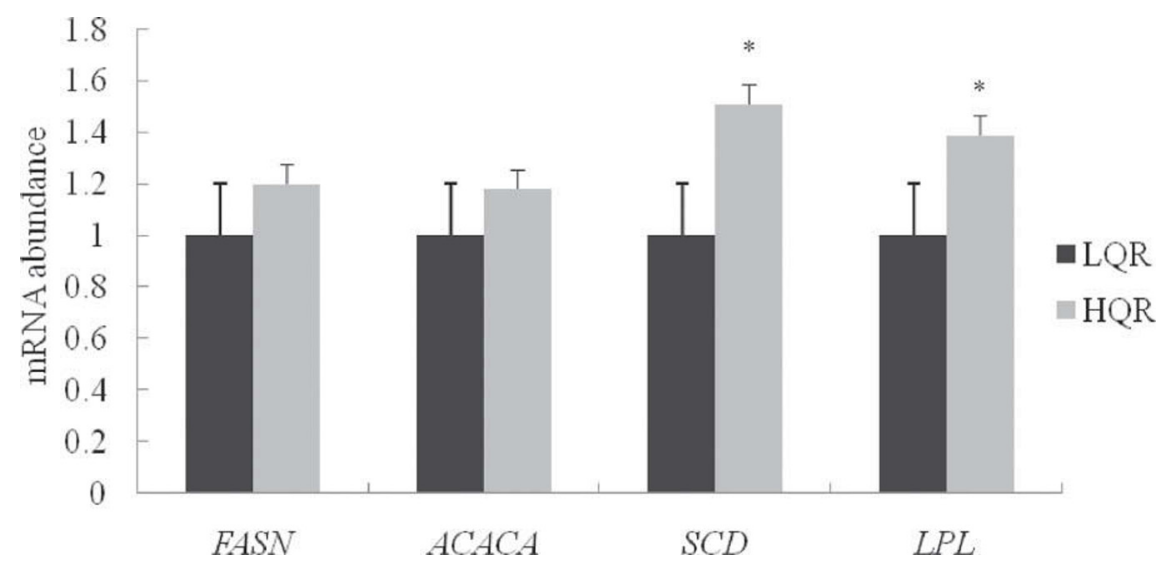

Figure 1. The effects of different diets on FA synthesis mRNA abundance for the genes encoding fatty acid synthase (FASN), acetylcoenzyme A carboxylase- $\alpha(A C A C A)$, stearoyl CoA desaturase $(S C D)$, and lipoprotein lipase $(L P L)$ from mammary tissue. The values for the low-quality roughage (LQR) diet was set to 1 , and values for the high-quality roughage (HQR) diet contrasted against these on an individual goat basis $(\mathrm{n}=8)$. An asterisk $\left(^{*}\right)$ indicates significant differences from values obtained in the LQR diet at $P<0.05$.

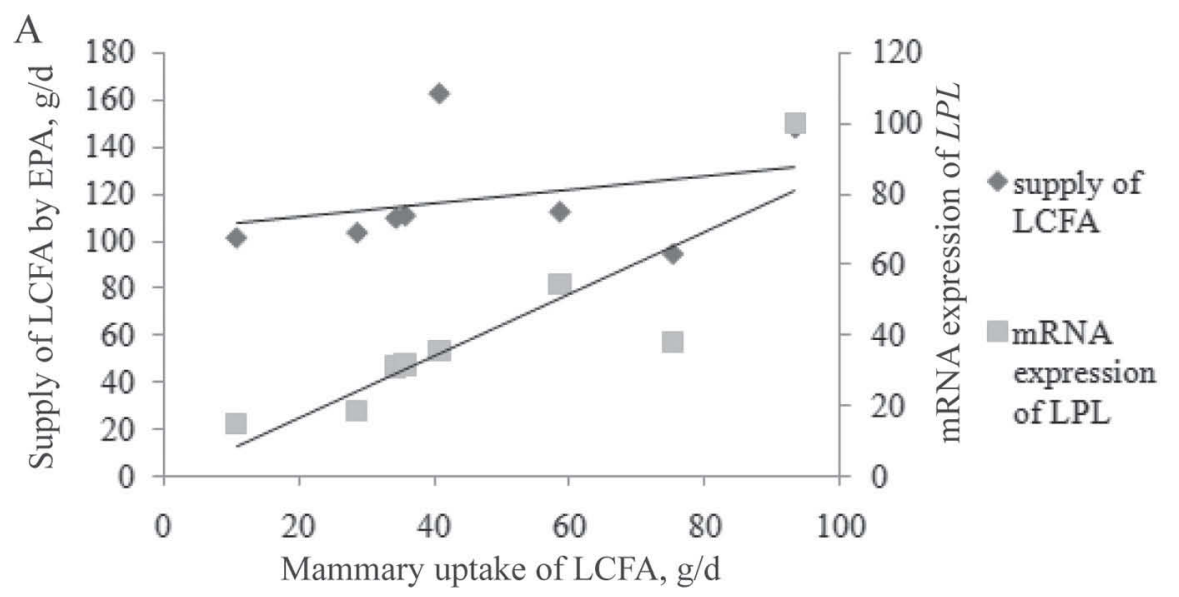

$\mathrm{B}$

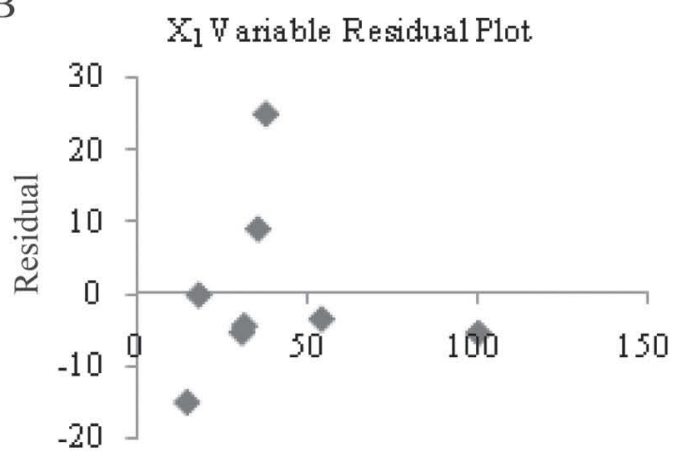

mRNA expression of $L P L$
$\mathrm{C}$

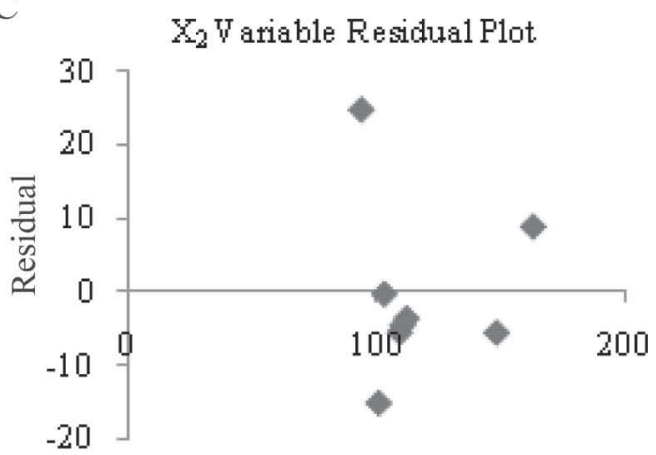

Supply of LCFA by EPA, g/d

Figure 2. The regression equation $(\mathrm{A}) \mathrm{Y}=98.31 \mathrm{X}_{1}-0.24 \mathrm{X}_{2}+35.38\left(\mathrm{R}^{2}=0.80, \mathrm{SE}=17.47, P=0.02, \mathrm{P}_{1}=0.01, \mathrm{P}_{2}=0.40\right.$. $)$ represents the relationships between mammary uptake of long-chain FA (LCFA) and supply of LCFA by external pudic artery (EPA), and mRNA expression of lipoprotein lipase $(L P L)$ by the mammary gland in lactating goats $(\mathrm{n}=8)$. The residual plot of the mRNA expression of $L P L(\mathrm{~B})$ and the supply of LCFA by EPA (C); Y represents the mammary uptake of LCFA, $\mathrm{X}_{1}$ represents the mRNA expression of $L P L, \mathrm{X}_{2}$ represents the supply of LCFA by EPA. P represents the overall $P$-value in the regression, and $\mathrm{P}_{1}$ and $\mathrm{P}_{2}$ represent the $P$-value of the slope of mRNA expression of $L P L$ and slope of supply of LCFA by EPA in the regression, respectively. 
A

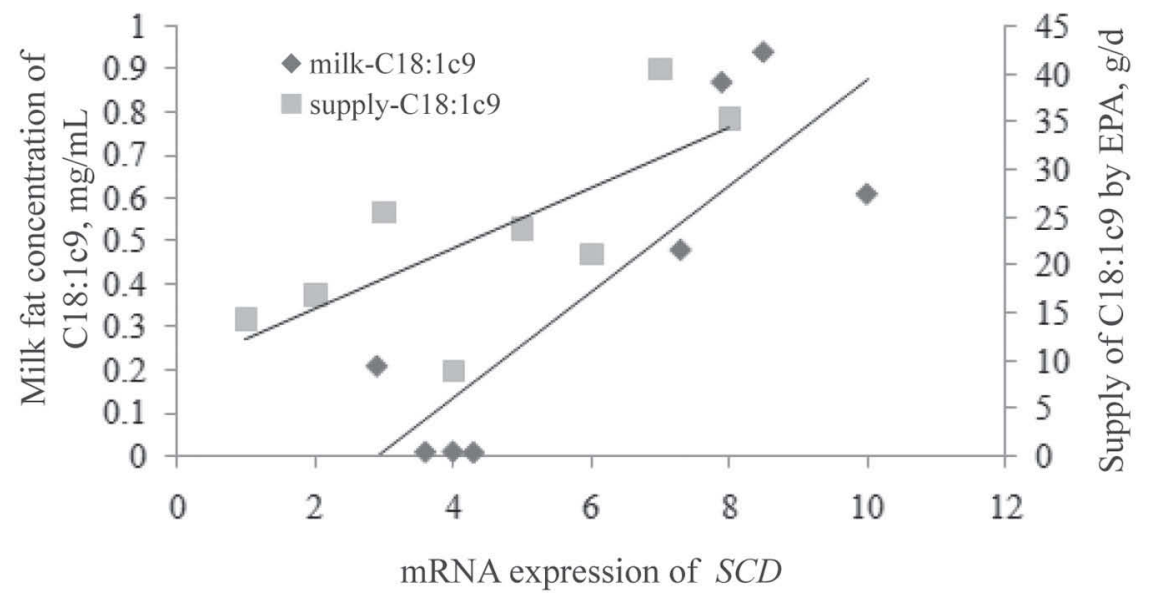

B

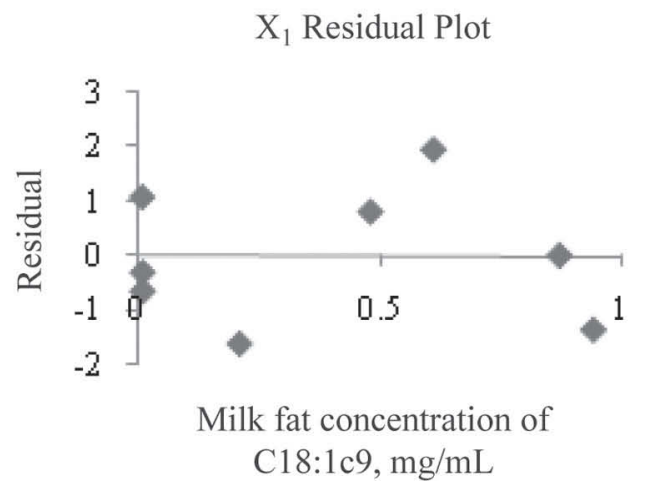

$\mathrm{C}$

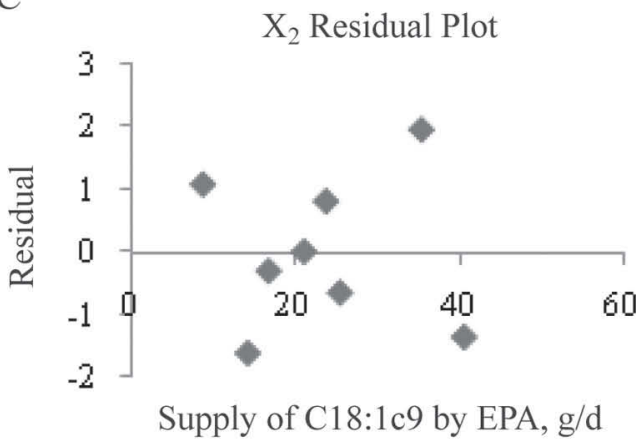

Figure 3. The regression equation $(\mathrm{A}) \mathrm{Y}=4.3 \mathrm{X}_{1}+0.09 \mathrm{X}_{2}+2.39\left(\mathrm{R}^{2}=0.78, \mathrm{SE}=1.39, P=0.02, \mathrm{P}_{1}=0.05, \mathrm{P}_{2}=0.29\right)$ represents the relationships between the mRNA abundance of stearoyl CoA desaturase $(S C D)$ in mammary gland and supply of C18:1 cis-9 by external pudic artery (EPA), and the milk fat concentration of C18:1 cis-9 of the 2 treatments in dairy goats $(\mathrm{n}=8)$. The residual plot of the milk fat concentration of C18:1 cis-9 (B) and the supply of C18:1 cis-9 by EPA (C); Y represents the mRNA expression of $S C D$, $\mathrm{X}_{1}$ represents the milk fat concentration of $\mathrm{C} 18: 1$ cis- $9, \mathrm{X}_{2}$ represents the supply of C18:1 cis-9 by EPA. $\mathrm{P}$ represents the overall $P$-value in the regression, and $\mathrm{P}_{1}$ and $\mathrm{P}_{2}$ represent the $P$-value of the slope of milk fat concentration of C18:1 cis-9 and slope of supply of C18:1 cis-9 by EPA in the regression, respectively.

delivery of FA into the mammary gland (Badaoui et al. 2007). The milk fat content in the present study significantly increased, and the milk fat of LCFA tended to increase in the goats fed HQR, which were affected by the $L P L$ activity in the mammary gland of the goats.

The increased expression of the $S C D$, an enzyme responsible for $\Delta^{9}$-desaturation of FA in the mammary gland, would result in increased UFA concentrations in the milk. An elevated level of UFA in milk is often regarded as a positive change in the nutritional properties of milk (Pintado and Gutierrez-Adan, 1999). The ratio between SFA and MUFA is influenced by $S C D$ (Garnsworthy et al., 2010). The conversion of C18:0 to C18:1 cis- 9 by $S C D$ accounts for approximately $60 \%$ of $\mathrm{C} 18: 1$ cis-9 found in milk (Salter et al., 2007). The mRNA expression level of $S C D$ in the mammary gland of goats was linear within the milk fat of $\mathrm{C} 18: 1$ cis-9 $(P=0.05)$, and the result was consistent with that of
Barber et al., (2000). The substrate supply of C18:1 cis-9 was not changed, thus the effect of the supply of $\mathrm{C} 18: 1$ cis-9 by EPA on the expression of $S C D$ was not significantly different $(P=0.29)$. The regression analysis demonstrated that the relationships between the mRNA abundance of $S C D$ in mammary gland and supply of C18:1 cis-9 by EPA and the milk fat concentration of $\mathrm{C} 18: 1$ cis-9 in dairy goats were significant $(P=0.02)$. The higher concentration of $\mathrm{C} 18: 1$ cis-9 in milk, compared with that in blood in both of the treatments in the present study indicated the activity of $S C D$ in the mammary gland. No changes were detected in the content of C18:0 in milk fat, but the content of C18:1 cis-9 in milk fat tended to increase in goats fed HQR due to increased $S C D$ activity detected in the mammary glands. The level of $S C D$ was higher with a concomitant increase in $\mathrm{C} 18: 1$ cis-9 in milk fat and a trend of lower SFA levels in goats fed the HQR diet. 


\section{CONCLUSIONS}

The current results demonstrated that the use of high-quality roughage is essential in increasing the milk fat content and milk fat yield in dairy goats. The mechanisms by which high-quality roughage modulates FA secretion are related to the level of mammary expression of genes encoding enzymes involved in $L P L$ and $S C D$. In addition, lactating goats feeding with a diet containing HQR changed the FA composition of their milk, with a tendency of decreasing the concentration of SFA and increasing the concentration of UFA. The concentrations of C18:1 cis-9 and C18:3n-3 observed in the milk of the goats fed HQR were higher compared with that in the goats fed LQR. The mammary gland balance of total FA increased, in goats fed with $\mathrm{HQR}$, whereas the clearance rate of total FA decreased. Moreover, diets with different quality roughage had a minimal effect on FA composition of plasma and mammary uptake.

\section{ACKNOWLEDGMENTS}

This work was funded by the National Basic Research Program of China (Beijing; 973,2011CB100803). We express our gratitude to the postgraduate students of Animal Science College of Inner Mongolia Agricultural University for their help with the collection of the experimental samples. We also acknowledge the kind contributions of Mingan Choct from University of New England (Armidale, Australia), and R. H. Zhang from Inner Mongolia Agricultural University.

\section{REFERENCES}

Badaoui, B., J. M. Serradilla, A. Tomas, B. Urrutia, J. L. Ares, J. Carrizosa, A. Sanchez, J. Jordana, and M. Amills. 2007. Short communication: Identification of two polymorphisms in the goat lipoprotein lipase gene and their association with milk production traits. J. Dairy Sci. 90:3012-3017.

Barber, M. C., R. J. Ward, S. E. Richards, A. M. Salter, P. J. Buttery, R. G. Vernon, and M. T. Travers. 2000. Ovine adipose tissue monounsaturated fat content is correlated to depot-specific expression of the stearoyl-CoA desaturase gene. J. Anim. Sci. 78:62-68.

Bauman, D. E., I. H. Mather, R. J. Wall, and A. L. Lock. 2006. Major advances associated with the biosynthesis of milk. J. Dairy Sci. 89:1235-1243.

Bernard, L., C. Leroux, M. Bonnet, J. Rouel, P. Martin, and Y. Chilliard. 2005. Expression and nutritional regulation of lipogenic genes in mammary gland and adipose tissues of lactating goats. J. Dairy Res. 72:250-255.

Bernard, L., C. Leroux, and Y. Chilliard. 2008. Expression and nutritional regulation of lipogenic genes in the ruminant lactating mammary gland. Adv. Exp. Med. Biol. 606:67-108.

Bernard, L., C. Leroux, Y. Faulconnier, D. Durand, K. J. Shingfield, and Y. Chilliard. 2009. Effect of sunflower-seed oil or linseed oil on milk fatty acid secretion and lipogenic gene expression in goats fed hay-based diets. J. Dairy Res. 76:241-248.
Broderick, G. A. 2003. Effects of varying dietary protein and energy levels on the production of lactating dairy cows. J. Dairy Sci. 86:1370-1381.

Chilliard, Y., C. Delouis, M. C. Smith, D. Sauvant, and P. MorandFehr. 1986. Mammary metabolism in the goat during normal orhormonally induced lactation. Reprod. Nutr. Dev. 26:607-615.

Chilliard, Y., A. Ferlay, and R. M. Mansbridge. 2000. Ruminant milk fat plasticity: Nutritional control of saturated, polyunsaturated, trans and conjugated fatty acids. Ann. Zootech. 49:181-205.

Chilliard, Y., F. Glasser, A. Ferlay, L. Bernard, J. Rouel, and M. Doreau. 2007. Diet, rumen biohydrogenation and nutritional quality of cow and goat milk fat. Eur. J. Lipid Sci. Technol. 109:828855.

Chouinard, P. Y., L. Corneau, A. Saebo, and D. E. Bauman. 1999. Milk yield and composition during abomasal infusion of conjugated linoleic acids in dairy cows. J. Dairy Sci. 82:2737-2745.

Colmenero, J. J., and G. A. Broderick. 2006. Effect of dietary crude protein concentration on milk production and nitrogen utilization in lactating dairy cows. J. Dairy Sci. 89:1704-1712.

Couvreur, S., C. Hurtaud, P. G. Marnet, P. Faverdin, and J. L. Peyraud. 2007. Composition of milk fat from cows selected for milk fat globule size and offered either fresh pasture or a corn silage-based diet. J. Dairy Sci. 90:392-403.

Delgado-Elorduy, A., C. B. Theurer, J. T. Huber, A. Alio, O. Lozano, M. Sadik, P. Cuneot, H. D. De Young, I. J. Simas, J. E. Santos, L. Nussio, C. Nussio, K. E. Webb Jr., and H. Tagari. 2002. Splanchnic and mammary nitrogen metabolism by dairy cows fed steamrolled or steam-flaked corn. J. Dairy Sci. 85:160-168.

Desnoyers, M., S. Giger-Reverdin, D. Sauvant, and C. Duvaux-Ponter. 2011. The use of a multivariate analysis to study between-goat variability in feeding behavior and associated rumen $\mathrm{pH}$ patterns. J. Dairy Sci. 94:842-852.

Dewhurst, R. J., N. D. Scollan, and S. J. Youell. 2001. Influence of species, cutting date and cutting interval on the fatty acid composition of grasses. Grass Forage Sci. 56:68-74.

Farr, V. C., K. Stelwagen, L. R. Cate, A. J. Molenaar, T. B. McFadden, and S. R. Davis. 1996. An improved method for the routine biopsy of bovine mammary tissue. J. Dairy Sci. 79:543-549.

Gagliostro, G., and Y. Chilliard. 1991. Duodenal rapeseed oil infusion in early and midlactation cows. 2. Voluntary intake, milk production, and composition. J. Dairy Sci. 74:499-509.

Garnsworthy, P. C., S. Feng, A. L. Lock, and M. D. Royal. 2010. Short communication: Heritability of milk fatty acid composition and stearoyl-CoA desaturase indices in dairy cows. J. Dairy Sci. 93:1743-1748.

Hamosh, M., T. R. Clary, S. S. Cherniek, and R. O. Scow. 1970. Lipoprotein lipase activity of adipose and mammary tissue and plasma triglyceride in pregnant and lactating rats. Biochim. Biophys. Acta 210:473-482.

Hanigan, M. D., J. France, D. Wray-Cahen, D. E. Beever, G. E. Lobley, L. Reutzel, and N. E. Smith. 1998. Alternative models for analyses of liver and mammary transorgan metabolite extraction data. Br. J. Nutr. 79:63-78.

Harvatine, K. J., Y. R. Boisclair, and D. E. Bauman. 2009. Recent advances in the regulation of milk fat synthesis. Animal 3:40-54.

Iverson, S. J., M. Hamosh, and W. D. Bowen. 1995. Lipoprotein lipase activity and its relationship to high milk fat transfer during lactation in grey seals. J. Comp. Physiol. B Biochem. Syst. Environ. Physiol. 165:384-395.

Jenkins, T. C., and M. A. McGuire. 2006. Major advances in nutrition: impact on milk composition. J. Dairy Sci. 89:1302-1310.

Katz, M. L., and E. N. Bergman. 1969. Simultaneous measurements of hepatic and portal venous blood flow in the sheep and dog. Am. J. Physiol. 216:946-952.

Kelly, M. L., E. S. Kolver, D. E. Bauman, M. E. Van Amburgh, and L. D. Muller. 1998. Effect of intake of pasture on concentrations of conjugated linoleic acid in milk of lactating cows. J. Dairy Sci. 81:1630-1636.

Livak, K. J., and T. D. Schmittgen. 2001. Analysis of relative gene expression data using real-time quantitative PCR and the $2^{(-\Delta \Delta \mathrm{CT})}$ method. Methods 25:402-408. 
Luna, P., A. Bach, M. Juarez, and M. A. de la Fuente. 2008. Effect of a diet enriched in whole linseed and sunflower oil on goat milk fatty acid composition and conjugated linoleic acid isomer profile. J. Dairy Sci. 91:20-28.

Min, B. R., S. P. Hart, T. Sahlu, and L. D. Satter. 2005. The effect of diets on milk production and composition, and on lactation curves in pastured dairy goats. J. Dairy Sci. 88:2604-2615.

Moate, P. J., W. Chalupa, R. C. Boston, and I. J. Lean. 2008. Milk fatty acids II: Prediction of the production of individual fatty acids in bovine milk. J. Dairy Sci. 91:1175-1188.

NRC. 2001. Nutrient Requirements of Dairy Cattle. 7th rev. ed. Natl. Acad. Press, Washington, DC.

NRC. 2007. Nutrient Requirements of Small Ruminants. Sheep, Goats, Cervids, and New World Camelids. Natl. Acad. Press, Washington, DC.

Nudda, A., G. Battacone, M. Decandia, M. Acciaro, F. Aghini-Lombardi, M. Frigeri, and G. Pulina. 2009. The effect of dietary iodine supplementation in dairy goats on milk production traits and milk iodine content. J. Dairy Sci. 92:5133-5138.

Odongo, N. E., M. M. Or-Rashid, R. Bagg, G. Vessie, P. Dick, E. Kebreab, J. France, and B. W. McBride. 2007. Long-term effects of feeding monensin on milk fatty acid composition in lactating dairy cows. J. Dairy Sci. 90:5126-5133.

Ollier, S., C. Leroux, A. de la Foye, L. Bernard, J. Rouel, and Y. Chilliard. 2009. Whole intact rapeseeds or sunflower oil in highforage or high-concentrate diets affects milk yield, milk composition, and mammary gene expression profile in goats. J. Dairy Sci. 92:5544-5560.
Patel, M., E. Wredle, and J. Bertilsson. 2013. Effect of dietary proportion of grass silage on milk fat with emphasis on odd- and branched-chain fatty acids in dairy cows. J. Dairy Sci. 96:390-397.

Pintado, B., and A. Gutierrez Adan. 1999. Trans genetics in large domestic species: Future development for milk modification. Reprod. Nutr. Dev. 39:535-544.

Salter, A. M., A. L. Lock, P. C. Garnsworthy, and D. E. Bauman. 2007. Milk fatty acids: Implications for human health. Pages 1-18 in Recent Advances in Animal Nutrition. 40th University of Nottingham Feed Conference, Nottingham, UK. CABI, Wallingford, UK.

Tagari, H., K. Webb Jr., B. Theurer, T. Huber, D. DeYoung, P. Cuneo, J. E. Santos, J. Simas, M. Sadik, A. Alio, O. Lozano, A. Delgado-Elorduy, L. Nussio, C. M. Bittar, and F. Santos. 2008. Mammary uptake, portal-drained visceral flux, and hepatic metabolism of free and peptide-bound amino acids in cows fed steamflaked or dry-rolled sorghum grain diets. J. Dairy Sci. 91:679-697.

Ten Have, T. R., J. R. Landis, and S. L. Weaver. 1995. Association models for periodontal disease progression: A comparison of methods for clustered binary data. Stat. Med. 14:413-429.

Weiss, W. P., and D. J. Wyatt. 2006. Effect of corn silage hybrid and metabolizable protein supply on nitrogen metabolism of lactating dairy cows. J. Dairy Sci. 89:1644-1653.

Zhu, W., Y. Fu, B. Wang, C. Wang, J. A. Ye, Y. M. Wu, and J. X. Liu. 2013. Effects of dietary forage sources on rumen microbial protein synthesis and milk performance in early lactating dairy cows. J. Dairy Sci. 96:1727-1734. 